\title{
Sistem Pakar Diagnosa Penyakit Kulit pada Manusia dengan Metode Dempster Shafer
}

\author{
(Expert System of Diagnosing Skin Disease of Human being using Dempster Shafer \\ Method)
}

\author{
Anita Rosana MZ, I Gede Pasek Suta Wijaya*, Fitri Bimantoro \\ Program Studi Teknik Informatika, Universitas Mataram \\ J1. Majapahit 62, Mataram, Lombok NTB, INDONESIA \\ Email: anitarosanamz@gmail.com, [gpsutawijaya,bimo]@unram.ac.id
}

*Penulis korespondensi

\begin{abstract}
Skin is the broadest organ in the human body that covers the entire surface of the body and acts as a support for human life. Because of its outermost location, the skin is often attacked by various diseases. This research aims to build an expert system to diagnose 10 types of skin diseases caused by viruses, fungi, bacteria, and parasites based on the knowledge of 3 experts using the Dempster Shafer method to obtain conclusions of skin diseases. Each symptom of skin disease has a value of belief that is used to calculate conclusions in the Dempster Shafer method. Expert system applications that are built can run on Android-based smartphones. Testing techniques used in this research are black-box testing, theoretical calculations, system accuracy and MOS (Mean Opinion Score). The theoretical calculation test concludes that the system calculation results have been appropriate with the results of manual calculations. System accuracy testing in $\mathbf{3 0}$ sample cases resulted in an accuracy of $90 \%$, but if it was seen as a subset of expert diagnosis, it resulted in a system accuracy of $92.22 \%$. MOS testing on 35 respondents results in a MOS value of 4.35 from a scale of 5 which shows that the system is proper to use and categorized into a good system.
\end{abstract}

Key words: Skin Disease, Experts, Expert System, Dempster Shafer, Android

\section{PENDAhUluAN}

Organ terluas yang menutupi seluruh permukaan tubuh manusia adalah kulit[1]. Kulit memiliki peran penting untuk menunjang hidup manusia, salah satunya sebagai indera peraba manusia[2]. Karena letaknya paling luar, kulit merupakan bagian yang secara langsung akan menerima rangsangan seperti sentuhan, rasa sakit dan pengaruh lainnya dari luar, sehingga berbagai penyakit sering kali menyerang kulit[3]. Kulit juga terkadang digunakan sebagai salah satu bentuk interaksi antar manusia sedangkan beberapa penyakit dapat tertular hanya dengan melalui interaksi kulit dengan kulit atau penggunaan media (handuk, baju, jaket, sapu tangan) bersama dengan orang yang memiliki penyakit kulit menular[2].

Penyakit dan gangguan pada kulit dapat disebabkan oleh berbagai faktor diantaranya yaitu infeksi mikroorganisme, daya tahan tubuh, reaksi alergi serta lingkungan dan kesehatan diri yang buruk[3]. Kulit yang terserang penyakit akan menimbulkan banyak akibat diantaranya yaitu gatal, kulit tidak dapat merasakan apa pun, kegagalan fungsi kulit, mengganggu penampilan dan aktivitas penderitanya[4]. Berdasarkan data Dinas Kesehatan Provinsi NTB, penyakit kulit merupakan 10 penyakit terbanyak di puskesmas di provinsi NTB tahun 2016 dan 2017 dengan total 186.318 kasus[5].

Konsultasi terkait penyakit kulit harus dilakukan dengan dokter ahli karena kesalahan dalam melakukan perawatan dan penanganan dapat membuat penyakit kulit menjadi lebih berbahaya[3]. Keterbatasan pengetahuan tentang penyakit kulit dapat menjadi salah satu faktor meningkatnya jumlah penderita penyakit kulit. Selain itu, keterbatasan jumlah dokter spesialis juga menjadi penyebab semakin parahnya penyakit kulit yang diderita pasien karena penyakit kulit tersebut terlambat ditangani. Menurut Data Dinas Kesehatan Provinsi NTB, rasio dokter spesialis di NTB sebesar 8,80 per 100.000 penduduk, dimana jumlah tersebut berada di bawah rasio yang ditetapkan yaitu sebesar 11 per 100.000 penduduk[5]. Oleh karena itu, dibutuhkan sebuah sistem yang dapat menirukan keahlian pakar yang diharapkan mampu meyelesaikan permasalahan khususnya di bidang kesehatan untuk kulit.

Perkembangan teknologi saat ini dimanfaatkan dalam dunia kesehatan untuk meningkatkan efisiensi dan efektivitas dengan menerapkan penggunaan sistem pakar. Sistem pakar dapat membantu untuk menyelesaikan masalah dengan cara mengumpulkan dan menyimpan pengetahuan pakar dalam basis pengetahuan kemudian melakukan penalaran seperti seorang pakar dalam mengambil keputusan. Salah satu metode pada sistem pakar adalah Dempster Shafer. Metode Dempster Shafer termasuk dalam metode penalaran non monotonis yang digunakan untuk menghitung ketidakkonsistenan karena adanya penambahan maupun pengurangan fakta baru yang akan merubah aturan yang ada, sehingga dengan menggunakan metode Dempster Shafer seseorang juga dapat mengetahui probabilitas atau persentase dari kemungkinan penyakit yang diderita[6]. 
Alasan penulis memilih metode Dempster Shafer diantaranya yaitu kemampuan metode Dempster Shafer untuk mengatasi ketidakkonsistenan dan ketidakpastian dalam deteksi. Proses perhitungan untuk penarikan kesimpulan dengan metode ini juga dirasa mudah karena hanya berdasarkan pada nilai belief yang diberikan langsung oleh pakar terhadap gejala suatu penyakit dan juga dapat menghitung probabilitas semua kemungkinan penyakit dari setiap gejala. Selain itu diantara metode penalaran non monotonis, penerapan metode Dempster Shafer memiliki akurasi yang lebih tinggi dibandingkan dengan metode Certainty Factor pada sistem pakar diagnosa penyakit diabetes melitus[7], penyakit mulut dan gigi[8] dan penyakit kelinci[9] serta memiliki akurasi yang sama dibandingkan dengan metode Bayesian Network pada sistem pakar diagnosa penyakit mata[10]. Metode Dempster Shafer memiliki akurasi yang lebih tinggi dibandingkan dengan metode Certainty Factor disebabkan oleh perbedaan mendasar dalam proses perhitungan, dimana perhitungan dari setiap kemungkinan penyakit pada metode Dempster Shafer selalu saling terkait dalam melakukan penalaran.

Penelitian yang menggunakan metode Dempster Shafer pada sistem pakar untuk mendiagnosa penyakit kulit pada manusia telah dilakukan sebelumnya[2][11][12][13]. Namun dalam penelitian terdahulu, nilai belief pada setiap gejala didapatkan hanya dari 1 pakar, sehingga hasil diagnosa pada sistem bersifat subjektif. Oleh karena itu, dibutuhkan data nilai belief dari beberapa pakar agar dapat mengurangi subjektivitas hasil diagnosa sistem dan meningkatkan keakuratan dalam hasil diagnosa.

Berdasarkan uraian di atas, maka penulis akan membangun sistem pakar untuk mendiagnosa penyakit kulit dengan menggunakan metode Dempster Shafer untuk mengetahui probabilitas dari penyakit yang diderita berdasarkan nilai kepercayaan pakar terhadap gejala yang dirasakan pasien. Nilai kepercayaan pada setiap gejala penyakit kulit didapatkan dari 3 pakar. Sistem pakar ini akan dibangun pada platform android karena sebagian besar masyarakat di Indonesia menggunakan smartphone android[14]. Aplikasi yang dibangun diharapkan dapat digunakan untuk meningkatkan kehati-hatian dan segera melakukan konsultasi dengan dokter untuk mendapatkan kepastian diagnosa dan terapi sejak dini, sehingga mengurangi kemungkinan menderita penyakit yang lebih berbahaya.

\section{TINJAUAN PUSTAKA DAN DASAR TEORI}

\section{A. Tinjauan Pustaka}

Penelitian tentang sistem pakar untuk mendiagnosa 14 jenis penyakit kulit dan kelamin dengan menggunakan metode Certainty Factor[15]. Sistem pakar ini dibangun menggunakan antarmuka android dan database SQLite. Pengujian akurasi sistem menghasilkan kesimpulan bahwa sistem memiliki rata-rata akurasi sebesar $87,5 \%$.

Penelitian tentang sistem pakar untuk mendiagnosa 10 penyakit kulit dan kelamin berbasis website dengan mengombinasikan metode Fuzzy Logic dan Certainty Factor [16]. Berdasarkan hasil pengujian 10 contoh kasus didapatkan rata-rata tingkat akurasi sistem sebesar $73 \%$.

Penelitian tentang sistem pakar berbasis desktop untuk mendiagnosa 6 jenis penyakit kulit akibat infeksi jamur dengan menggunakan metode Bayesian Network[17]. Metode Bayesian Network berhasil diterapkan dalam sistem pakar penyakit kulit.

Penelitian tentang sistem pakar berbasis web untuk mendiagnosa 6 jenis penyakit kulit pada manusia dengan menggunakan metode Dempster Shafer[2]. Kekurangan pada penelitiam ini yaitu hasil diagnosa sistem tidak dapat menampilkan persentase keyakinan pasien terdiagnosa penyakit kulit dan tidak diketahui bagaimana performa metode Dempster Shafer dalam memberikan hasil diagnosa, sehingga tidak dapat diketahui kesesuaian antara hasil sistem dengan hasil diagnosa pakar.

Penelitian tentang sistem pakar berbasis desktop untuk mendiagnosa 15 jenis penyakit kulit dengan menggunakan metode Dempster Shafer[12]. Nilai kepercayaan suatu gejala didapatkan dari 1 pakar (dokter spesialis kulit dan kelamin). Sistem pakar ini menghasilkan akurasi sebesar $70 \%$.

Penelitian tentang sistem pakar untuk mendiagnosa 10 jenis penyakit kulit dengan menerapkan metode Dempster Shafer[11]. Penelitian ini hanya menghasilkan aplikasi prototype sistem pakar berbasis website yang dapat menampilkan hasil diagnosa berupa nama penyakit yang diderita beserta persentasenya. Nilai kepercayaan terhadap suatu gejala didapatkan dari 1 pakar (dokter spesialis kulit dan kelamin). Berdasarkan pengujian 5 contoh kombinasi gejala disimpulkan bahwa perbandingan diagnosa antara pakar dan sistem memiliki selisih sekitar 5-8\%.

Penelitian tentang sistem pakar berbasis web untuk mendiagnosa 8 penyakit gangguan mental pada anak usia 4-17 tahun dengan metode Dempster Shafer[18]. Nilai kepercayaan suatu gejala didapatkan berdasarkan jawaban dari 3 pakar. Sistem pakar ini menghasilkan tingkat akurasi sebesar $95 \%$ dari 40 kasus rekam medis.

Penelitian tentang sistem pakar berbasis web untuk mendiagnosa 7 jenis penyakit tanaman padi dengan menggunakan metode Dempster Shafer[19]. Hasil dari pengujian akurasi 20 kasus uji yaitu $90 \%$.

Penelitian tentang analisa perbandingan metode Fuzzy Mamdani dan Dempster Shafer pada sistem pakar untuk mendiagnosa 10 jenis penyakit kulit[13]. Kedua metode menghasilkan nilai kesesuaian sebesar $100 \%$. Nilai kepercayaan terhadap suatu gejala pada metode Dempster Shafer didapatkan dari 1 orang pakar. Penggunaan metode Dempster Shafer dalam diagnosa disimpulkan lebih mudah dibandingkan dengan metode Fuzzy Mamdani berdasarkan pada hasil kepuasan pengguna saat menggunakan sistem pakar penyakit kulit.

Penelitian tentang analisa perbandingan hasil diagnosa metode Certainty Factor dan Dempster Shafer pada sistem pakar berbasis web untuk mendiagnosa 9 jenis penyakit kelinci[9]. Hasil pengujian 20 kasus penyakit kelinci menyimpulkan bahwa metode Dempster Shafer lebih tepat 
digunakan untuk mendiagnosa penyakit kelinci dibandingkan dengan metode Certainty Factor karena metode Dempster Shafer menghasilkan akurasi yang lebih tinggi yaitu sebesar $85 \%$ sedangkan metode Certainty Factor menghasilkan akurasi sebesar $80 \%$

Penelitian tentang analisa perbandingan metode Certainty Factor dan Dempster Shafer pada sistem pakar berbasis web untuk mendiagnosa 3 jenis penyakit diabetes melitus[7]. Pengujian pada sampel 100 data pasien menghasilkan akurasi yang sama pada kedua metode yaitu sebesar 99\%. Penelitian ini menyimpulkan bahwa metode Dempster Shafer lebih tepat untuk digunakan dalam mendiagnosa penyakit diabetes melitus dengan tingkat signifikasi 0,05 berdasarkan hasil uji T.

Penelitian tentang analisis perbandingan metode Bayesian Network dan Dempster Shafer pada sistem pakar untuk mendiagnosia 6 jenis penyakit mata[10]. Berdasarkan pengujian 7 sampel pasien disimpulkan bahwa kedua metode sama baiknya dalam melakukan diagnosa karena kedua metode menghasilkan akurasi yang sama yaitu sebesar $85,7 \%$.

Berdasarkan tinjauan pustaka dari beberapa penelitian tersebut, maka penulis akan membangun sistem pakar untuk mendiagnosa 10 penyakit kulit pada manusia yang disebabkan oleh jamur, virus, bakteri dan parasit dengan menggunakan metode Dempster Shafer untuk mendapatkan kesimpulan. Nilai kepercayaan setiap gejala didapatkan berdasarkan jawaban dari 3 pakar yaitu dokter spesialis kulit dan kelamin. Sistem pakar ini akan dibangun pada platform Android. Fitur yang diberikan sistem pada penelitian ini adalah pengguna (masyarakat umum) dapat melakukan diagnosis penyakit kulit dengan memilih gejala yang dialami pasien, melihat hasil diagnosa penyakit yang diderita oleh pasien, melihat riwayat diagnosa, melihat informasi penyakit kulit beserta saran penanganan dan pencegahan yang dapat dilakukan, serta pengguna dapat melihat panduan penggunaan sistem.

\section{B. Dasar Teori}

\section{B.1. Dempster Shafer}

Dempster Shafer ditulis dalam rentang nilai yaitu Belief dan Plausibility. Belief dan plausibility ditulis dalam interval nilai $[0,1]$. Belief ( $\mathrm{Bel}$ ) merupakan parameter nilai kepercayaan atas evidence dalam perhitungan himpunan proposisi. Jika belief bernilai 1 maka membuktikan adanya keyakinan dari evidence dan jika bernilai 0 maka menunjukkan tidak adanya keyakinan dari evidence. Plausibility $(P l s)$ adalah parameter dari nilai ketidakyakinan atas suatu evidence yang akan menurunkan tingkat keyakinan dari evidence. Jika terdapat keyakinan pada penyakit $(\mathrm{X})$, maka nilai $\operatorname{Bel}(X)$ adalah 1 , sehingga nilai $P l s(X)$ akan bernilai 0. Fungsi Belief diformulasikan seperti pada Persamaan (1) dan fungsi Plausibility diformulasikan seperti pada Persamaan (2)[18].

$$
\begin{gathered}
\operatorname{Bel}(\mathrm{X})=\sum_{\mathrm{Y} \subseteq \mathrm{X}} m_{1}(\mathrm{X}) \\
P l s(\mathrm{X})=1-\operatorname{Bel}(\mathrm{X})
\end{gathered}
$$

dimana:

$\mathrm{X}=$ Penyakit yang mengalami gejala 1

$\mathrm{Y} \quad=$ Penyakit yang mengalami gejala 2

$\operatorname{Bel}(\mathrm{X})=\operatorname{Belief}(\mathrm{X})$, artinya nilai keyakinan atau kepastian penyakit $\mathrm{X}$ yang mengalami gejala 1

$P l s(\mathrm{X})=$ Plausibility $(\mathrm{X})$, artinya nilai ketidakyakinan atau ketidakpastian penyakit $\mathrm{X}$ yang mengalami gejala 1

$\mathrm{m}_{1}(\mathrm{X})=$ Mass function atau tingkat kepercayaan dari evidence $(\mathrm{X})$

Pada teori Dempster Shafer terdapat suatu environment yang merupakan himpunan semesta dari kumpulan hipotesis. Environment berisikan sekumpulan elemen dari kemungkinan jawaban dan hanya terdapat satu elemen yang akan sesuai dengan jawaban yang dibutuhkan.

Mass function (m) dalam teori Dempster Shafer merupakan ukuran keyakinan dari suatu evidence (gejala)[19]. Apabila diketahui X dan Y merupakan himpunan bagian dari $\theta$, dengan $\mathrm{ml}$ sebagai fungsi densitas $\mathrm{X}$ dan $\mathrm{m} 2$ sebagai fungsi densitas $\mathrm{Y}$, maka dapat dibentuk $\mathrm{m} 3$ sebagai fungsi kombinasi dari $\mathrm{m} 1 \mathrm{dan} \mathrm{m} 2$ yang diformulasikan seperti pada Persamaan (3).

$$
\mathrm{m} 3(\mathrm{Z})=\frac{\sum_{\mathrm{X} \cap \mathrm{Y}=\mathrm{Z}} \mathrm{m} 1(\mathrm{X}) \cdot \mathrm{m} 2(\mathrm{Y})}{1-\sum_{\mathrm{X} \cap \mathrm{Y}=\varnothing} \mathrm{m} 1(\mathrm{X}) \cdot \mathrm{m} 2(\mathrm{Y})}
$$

dimana:

$\mathrm{m} 3(\mathrm{Z})=$ Mass function dari evidence $(\mathrm{Z})$, di mana $\mathrm{Z}$ adalah nilai densitas baru hasil irisan dari $\mathrm{m} 1(\mathrm{X})$ dan $\mathrm{m} 2(\mathrm{Y})$ dibagi dengan 1 dikurangi irisan kosong $(\varnothing)$ dari $\mathrm{m} 1(\mathrm{X})$ dan $\mathrm{m} 2(\mathrm{Y})$.

$\mathrm{m} 1(\mathrm{X})=$ Mass function atau tingkat kepercayaan dari evidence $(\mathrm{X})$, dimana $\mathrm{X}$ adalah penyakit yang mengalami gejala 1 .

$\mathrm{m} 2(\mathrm{Y})=$ Mass function atau tingkat kepercayaan dari evidence (Y), di mana $\mathrm{Y}$ adalah penyakit yang mengalami gejala 2 .

Akuisisi pengetahuan pada metode Dempster Shafer dilakukan dengan mengumpulkan data dari berbagai studi literatur dan wawancara. Pemberian kuesioner kepada pakar dilakukan untuk memperoleh data nilai kepercayaan terhadap suatu gejala. Alternatif jawaban yang dapat diisi oleh pakar pada kuesioner dapat dilihat pada Tabel I.

TABEL I. NILAI ALTERNATIF JAW ABAN KUESIONER [18]

\begin{tabular}{|l|c|}
\hline Kepercayaan terhadap suatu gejala & $\begin{array}{c}\text { Nilai kepercayaan } \\
\text { (Belief) }\end{array}$ \\
\hline Sangat tidak setuju & 0.05 \\
\hline Tidak setuju & 0.25 \\
\hline Netral & 0.5 \\
\hline Setuju & 0.85 \\
\hline Sangat setuju & 1 \\
\hline
\end{tabular}

Nilai akhir kepercayaan terhadap suatu gejala akan digunakan pada mesin inferensi untuk perhitungan metode Dempster Shafer. Nilai akhir kepercayaan (Nak) pada gejala X dihitung dengan Persamaan (4)[18]: 


$$
\operatorname{Nak}(\mathrm{x})=\frac{\sum_{i=1}^{N} N B p i}{N}
$$

dimana NBpi adalah nilai belief pakar ke-i dan $\mathrm{N}$ adalah jumlah pakar.

\section{B.2. Penyakit Kulit pada Manusia}

Penyakit kulit dapat menyerang keseluruhan atau sebagian tubuh tertentu dan dapat menyerang siapa saja dari segala usia. Berikut ini merupakan 10 jenis penyakit kulit yang akan didiagnosa oleh sistem pada penelitian yang dilakukan.
1. Scabies
2. Tinea
3. Candidiasis
4. Varicella
5. Herpes Zoster
6. Impetigo Krustosa
7. Impetigo Bulosa
8. Selulitis
9. Karbunkel
10. Cutaneous Larva Migran

\section{Metode PENELITIAN}

\section{A. Proses Penelitian}

Pada tahap ini dilakukan beberapa tahapan hingga didapatkan suatu kesimpulan. Tahapan-tahapan yang dilakukan dalam proses penelitian digambarkan dalam diagram alir penelitian pada Gambar 1 .

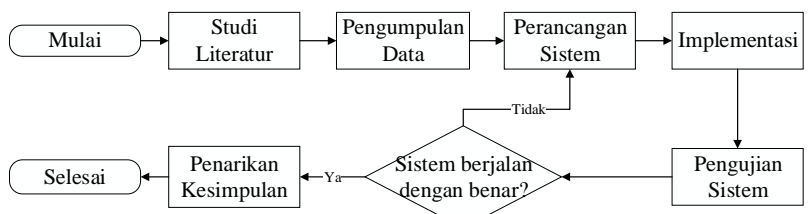

Gambar 1. Diagram alir proses penelitian sistem pakar diagnosa penyakit kulit pada manusia.

Berikut adalah penjelasan mengenai langkah-langkah penelitian berdasarkan pada Gambar 1.

\section{A.1. Studi Literatur}

Studi literatur yang dilakukan pada penelitian ini berkaitan dengan penyakit kulit pada manusia dan penerapan metode Dempster Shafer pada sistem pakar. Sumber-sumber literatur berupa jurnal ilmiah, skripsi, paper maupun sumber lain yang berkaitan dengan penelitian ini nantinya dijadikan sebagai referensi untuk mengembangkan sistem yang akan dibangun.

\section{A.2. Pengumpulan Data}

Pengumpulan data pada penelitian ini dilakukan dengan cara wawancara pada pakar. Wawancara dilakukan di RSUD Kota Mataram dan pakar pada penelitian yaitu dokter spesialis kulit dan kelamin. Informasi yang diberikan oleh pakar diantaranya yaitu mengenai deskripsi, penyebab, gejala, saran penanganan dan pencegahan serta nilai kepercayaan (belief) gejala penyakit kulit pada manusia. Informasi tersebut diberikan oleh dr. Angelica Vanini W. Taufiq, Sp.KK yang aktif bekerja pada RSUD Kota Mataram, Rafa Skin Clinic dan Apotek Medismart Kota Mataram. Pakar lain yang membantu untuk memberikan nilai kepercayaan gejala penyakit kulit adalah dr. Wiwin Mulianingsih, Sp.KK., M.Kes dan dr. Dedianto Hidajat, Sp.KK.

\section{A.3. Perancangan Sistem}

Tahap perancangan sistem merupakan tahap untuk memberikan gambaran tentang sistem yang akan dibangun, terdiri dari perancangan arsitektur sistem dan perancangan antarmuka sistem.

\section{A.4. Implementasi}

Pada tahap implementasi, rancangan sistem yang telah dibuat sebelumnya akan diimplementasikan ke dalam program.

\section{A.5. Pengujian Sistem}

Pengujian sistem yang dilakukan pada penelitian ini adalah pengujian akurasi sistem, pengujian blackbox, pengujian MOS (Mean Opinion Score) dan pengujian perhitungan teoritis. Jika dalam tahap pengujian, sistem menampilkan hasil yang tidak sesuai, maka akan dilakukan analisa kembali pada tahap perancangan sistem. Apabila sistem telah menampilkan hasil perhitungan yang sesuai dengan perhitungan manual, maka sistem dapat dinyatakan telah berjalan dengan benar dan selanjutnya dilakukan proses penarikan kesimpulan.

\section{A.6. Penarikan Kesimpulan}

Penarikan kesimpulan didapatkan berdasarkan hasil dari pengujian sistem yang telah dilakukan. Kesimpulan ditarik berdasarkan kesesuaian sistem yang dibangun dengan tujuan penelitian serta kebutuhan informasi pengguna sistem.

\section{B. Arsitektur Sistem Pakar Diagnosa Penyakit Kulit}

Sistem pakar terdiri dari dua bagian pokok yaitu lingkungan pengembangan dan lingkungan konsultasi. Ilustrasi arsitektur sistem pakar diagnosa penyakit kulit pada manusia yang dibangun dapat dilihat pada Gambar 2 .

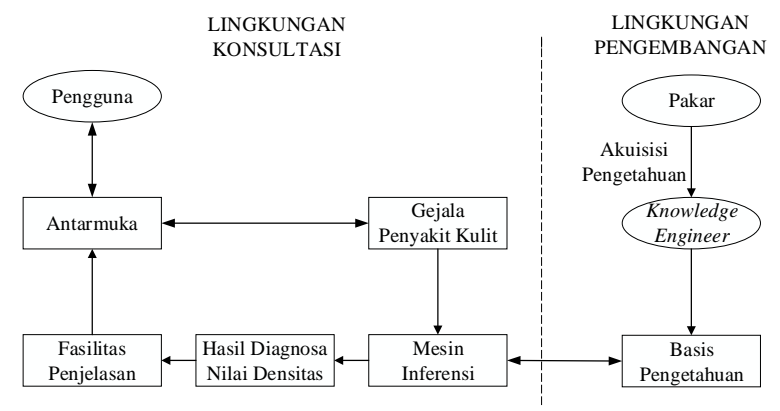

Gambar 2. Arsitektur sistem pakar diagnosa penyakit kulit pada manusia.

Perhitungan metode Dempster Shafer dilakukan pada bagian arsitektur sistem yaitu mesin inferensi. Mesin inferensi berperan sebagai otak dari sistem pakar yang 
berfungsi untuk memandu dalam proses penalaran sistem berdasarkan pada basis pengetahuan. Metode inferensi yang digunakan pada sistem pakar diagnosa penyakit kulit ini adalah forward chaining, dimana proses penalarannya dilakukan dengan menganalisa data masukan berupa gejala penyakit untuk mendapatkan hasil diagnosa berupa jenis penyakit kulit sebagai kesimpulan sistem. Pengguna dapat memilih 1 gejala untuk mendapatkan hasil diagnosa, namun pengguna disarankan memilih minimal 3 gejala untuk memperkuat pengambilan kesimpulan penyakit.

Algoritma mesin inferensi dengan menggunakan metode Dempster Shafer digambarkan pada Gambar 3. Penalaran mesin inferensi pada Gambar 3 dimulai dari fakta berupa gejala penyakit kulit yang dipilih oleh pasien. Setiap gejala terpilih memiliki nilai belief yang diperoleh dari 3 pakar dan kemudian dihitung nilai akhir kepercayaan dari setiap gejala menggunakan Persamaan (5) untuk digunakan dalam proses perhitungan. Setelah nilai belief setiap gejala diperoleh, maka akan dihitung nilai plausibility masing-masing gejala berdasarkan Persamaan (2). Proses perhitungan dengan metode Dempster Shafer akan membandingkan setiap nilai belief dari dua gejala awal yang dipilih untuk seterusnya dibandingkan dengan nilai belief dari gejala lain menggunakan Persamaan (3). Jika seluruh gejala telah diproses, maka akan didapatkan nilai densitas terbesar yang akan mengacu pada suatu penyakit.

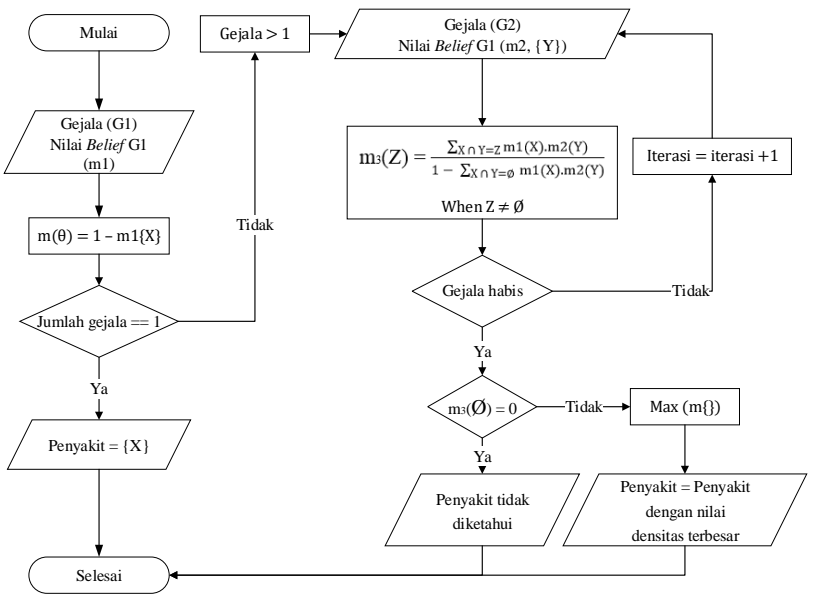

Gambar 3. Algoritma mesin inferensi dengan menggunakan metode Dempster Shafer.

\section{Nilai Belief Suatu Gejala terhadap Suatu Penyakit}

Perhitungan nilai kepastian atau densitas dalam diagnosa penyakit kulit dengan metode Dempster Shafer memerlukan nilai belief dari gejala yang ada. Nilai belief didapatkan dari pengetahuan dan pengalaman pakar saat melakukan diagnosa penyakit kulit dimana nilai belief pada metode Dempster Shafer berada pada interval nilai 0 sampai 1. Nilai belief yang diberikan masing-masing pakar akan digabungkan untuk mendapatkan nilai akhir kepercayaan (belief) gejala untuk setiap penyakit kulit yang dihitung dengan Persamaan (5).
Nilai akhir kepercayaan gejala (X)

$=\frac{\text { nilai belief pakar } 1+\text { nilai belief pakar } 2+\text { nilai belief pakar } 3}{3}$

\section{HASIL DAN PEMBAHASAN}

\section{A. Implementasi Sistem Pakar}

Implementasi sistem pakar ini akan membahas mengenai cara kerja sistem serta antarmuka dari halaman konsultasi dan hasil diagnosa dari sistem pakar diagnosa penyakit kulit pada manusia yang dibangun.

Halaman konsultasi pasien pada Gambar 4 menampilkan seluruh gejala penyakit kulit yang tersimpan dalam database pada satu halaman konsultasi. Pengguna yang akan melakukan konsultasi harus melakukan klik atau centang pada kotak atau checkbox di setiap gejala yang dirasakan oleh pasien. Setelah pengguna memilih seluruh gejala yang dirasakan, maka selanjutnya pengguna harus menekan tombol diagnosa untuk melihat hasil diagnosa penyakit kulit yang diderita oleh pasien.

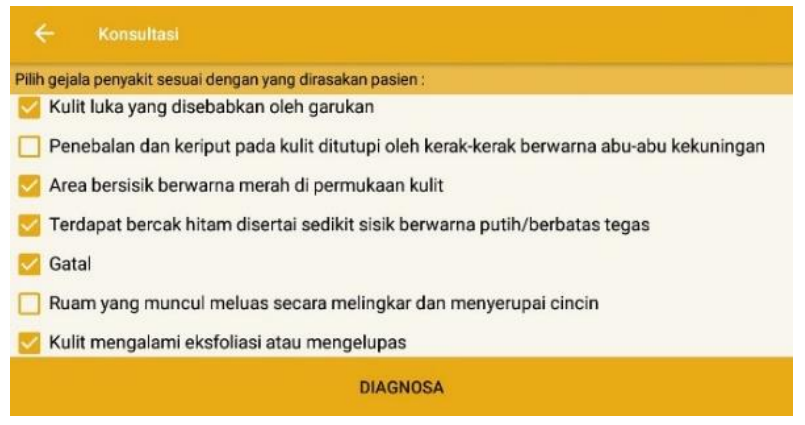

Gambar 4. Halaman konsultasi.

Halaman hasil diagnosa menampilkan kemungkinan penyakit kulit yang diderita pasien beserta persentasenya. Selain itu, gejala yang telah dipilih oleh pasien akan ditampilkan pada halaman ini. Informasi mengenai detail dari penyakit kulit yang diderita pasien akan ditampilkan ketika pengguna menekan pada nama penyakitnya. Halaman hasil diagnosa dan detail penyakit dapat dilihat pada Gambar 5.
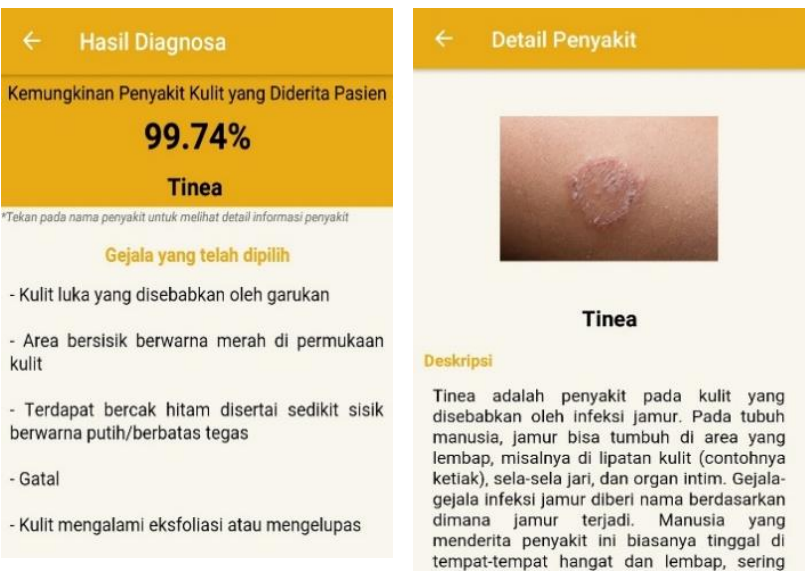

Gambar 5. Halaman hasil diagnosa dan detail penyakit. 


\section{B. Pengujian Sistem}

Pengujian sistem dilakukan untuk mengetahui kesesuaian hasil yang diberikan oleh sistem serta kelayakan dari sistem pakar diagnosa penyakit kulit pada manusia yang dibangun.

\section{B.1. Pengujian Black Box}

Pengujian black box dilakukan oleh 5 responden yaitu 5 orang mahasiswa Teknik Informatika dengan tujuan untuk menguji fungsionalitas dari sistem pakar diagnosa penyakit kulit pada manusia yang dibangun, dimana pengujian ini dilakukan dengan melihat keluaran yang dihasilkan oleh sistem berdasarkan pada kondisi masukan yang diberikan untuk setiap fungsi yang ada pada sistem. Berdasarkan hasil pengujian black box pada fungsionalitas dari laman info penyakit, konsultasi, panduan penggunaan, riwayat dan tentang aplikasi dapat disimpulkan bahwa sistem pakar diagnosa penyakit kulit pada manusia dengan metode Dempster Shafer yang dibangun telah berjalan sesuai dengan fungsionalitasnya atau disimpulkan memiliki kesesuaian sebesar $100 \%$ karena 5 responden memberikan hasil yang sama yaitu hasil pengujian sesuai dengan yang diharapkan.

\section{B.2. Pengujian Perhitungan Teoritis}

Pengujian perhitungan teoritis dilakukan pada 1 contoh kasus dengan tujuan untuk mengetahui kesesuaian antara persentase hasil perhitungan manual dan persentase hasil perhitungan sistem. Contoh kasus perhitungan teoritis dapat dilihat pada Tabel II.

TABEL II. CONTOH KASUS PERHITUNGAN TEORITIS

\begin{tabular}{|l|l|l|}
\hline \multicolumn{1}{|c|}{ Gejala } & \multicolumn{1}{|c|}{ Nama Penyakit } & \multicolumn{1}{c|}{$\begin{array}{c}\text { Nilai } \\
\text { Belief }\end{array}$} \\
\hline \multirow{5}{*}{ Gatal } & (P2) Tinea & 0.78 \\
\cline { 2 - 3 } & (P3) Candidiasis & 0.78 \\
\cline { 2 - 3 } & $\begin{array}{l}\text { (P10) Cutaneous Larva } \\
\text { Migran }\end{array}$ & 0.95 \\
\hline Merah pada kulit & (P3) Candidiasis & 0.78 \\
\hline $\begin{array}{l}\text { Kulit berwarna merah atau } \\
\text { putih yang menyebabkan gatal } \\
\text { dan iritasi }\end{array}$ & (P3) Candidiasis & 0.73 \\
\hline $\begin{array}{l}\text { Muncul pada kulit, kuku, mulut } \\
\text { atau vagina }\end{array}$ & (P3) Candidiasis & 0.95 \\
\hline Nyeri & (P5) Herpes Zoster & 0.83 \\
\cline { 2 - 3 } & (P6) Impetigo Krustosa & 0.62 \\
\cline { 2 - 3 } & (P8) Selulitis & 1 \\
\cline { 2 - 3 } & (P9) Karbunkel & 0.95 \\
\hline
\end{tabular}

a. Gejala G01: Gatal

$$
\begin{aligned}
& \mathrm{m}_{1}\{\mathrm{P} 2, \mathrm{P} 3, \mathrm{P} 10\}=\frac{0.78+0.78+0.95}{3}=0.8366 \\
& \mathrm{~m}_{1}\{\theta\}=1-0.8366=0.1634
\end{aligned}
$$

b. Gejala G02: Merah pada kulit

$$
\begin{aligned}
& \mathrm{m}_{2}\{\mathrm{P} 3\}=0.78 \\
& \mathrm{~m}_{2}\{\theta\}=1-0.78=0.22
\end{aligned}
$$

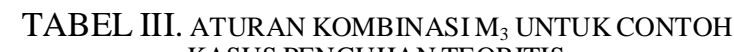
KASUS PENGUJIAN TEORITIS

$\mathrm{m} 1$

\begin{tabular}{|l|l|}
\hline \multicolumn{2}{|c|}{$\mathrm{m} 2$} \\
\hline $\mathrm{m} 2\{\mathrm{P} 3\}=0.78$ & $\mathrm{~m} 2\{\theta\}=0.22$ \\
\hline
\end{tabular}

\begin{tabular}{|l|l|l|}
\hline $\mathrm{m} 1\{\mathrm{P} 2, \mathrm{P} 3, \mathrm{P} 10\}$ & $\{\mathrm{P} 3\}=0.78 \mathrm{x}$ & $\{\mathrm{P} 2, \mathrm{P} 3, \mathrm{P} 10\}=0.22$ \\
$=0.8366$ & $0.8366=0.6526$ & $\mathrm{x} 0.8366=0.1840$ \\
\hline $\mathrm{m} 1\{\theta\}=0.1634$ & $\{\mathrm{P} 3\}=0.78 \mathrm{x}$ & $\{\theta\}=0.22 \times 0.1634=$ \\
& $0.1634=0.1274$ & 0.0359 \\
\hline
\end{tabular}

Sehingga dapat dihitung sebagai berikut:

$\mathrm{m}_{3}\{\mathrm{P} 3\}=\frac{0.6525+0.1274}{1-0}=0.78$

$\mathrm{m}_{3}\{\mathrm{P} 2, \mathrm{P} 3, \mathrm{P} 10\}=\frac{0.1840}{1-0}=0.1840$

$\mathrm{m}_{3}\{\theta\}=1-(0.78+0.1840)=0.036$

c. Gejala G03: Kulit berwarna merah atau putih yang menyebabkan gatal dan iritasi

$\mathrm{m}_{4}\{\mathrm{P} 3\}=0.73$

$\mathrm{m}_{4}\{\theta\}=1-0.73=0.27$

TABEL IV . ATURAN KOMBINASI $\mathrm{M}_{5}$ UNTUK CONTOH KASUS PENGUJIAN TEORITIS

\begin{tabular}{|l|l|l|}
\hline \multirow{2}{*}{$\mathrm{m} 3$} & \multicolumn{2}{|c|}{$\mathrm{m} 4$} \\
\cline { 2 - 3 } & \multicolumn{1}{|c|}{$\mathrm{m} 4\{\mathrm{P} 3\}=0.73$} & \multicolumn{1}{|c|}{$\mathrm{m} 4\{\theta\}=0.27$} \\
\hline \multirow{2}{*}{$\mathrm{m} 3\{\mathrm{P} 3\}=0.78$} & $\{\mathrm{P} 3\}=0.73 \times 0.78=$ & $\{\mathrm{P} 3\}=0.27 \times 0.78=$ \\
$\mathrm{m} 3\{\mathrm{P} 2, \mathrm{P} 3$, & 0.5694 & 0.2106 \\
$\mathrm{P} 10\}=0.1840$ & $\{\mathrm{P} 3\}=0.73 \times 0.1840$ & $\{\mathrm{P} 2, \mathrm{P} 3, \mathrm{P} 10\}=0.27$ \\
& $=0.13432$ & $\mathrm{x} 0.1840=0.0497$ \\
\hline \multirow{2}{*}{$\mathrm{m} 3\{\theta\}=0.036$} & $\{\mathrm{P} 3\}=0.73 \times 0.036=$ & $\{\theta\}=0.27 \times 0.036=$ \\
& 0.02628 & 0.0097 \\
\hline
\end{tabular}

Sehingga dapat dihitung sebagai berikut:

$\mathrm{m}_{5}\{\mathrm{P} 3\}=\frac{0.5694+0.13432+0.2106+0.02628}{1-0}=0.9406$

$\mathrm{m}_{5}\{\mathrm{P} 2, \mathrm{P} 3, \mathrm{P} 10\}=\frac{0.0497}{1-0}=0.0497$

$\mathrm{m}_{5}\{\theta\}=1-(0.9406+0.0497)=0.0097$

d. Gejala G04: Muncul pada kulit, kuku, mulut atau vagina

$\mathrm{m}_{6}\{\mathrm{P} 3\}=0.95$

$\mathrm{m}_{6}\{\theta\}=1-0.95=0.05$

TABEL V . ATURAN KOMBINASI M 7 UNTUK CONTOH KASUS PENGUJIAN TEORITIS

\begin{tabular}{|l|l|l|}
\hline \multirow{2}{*}{$\mathrm{m} 5$} & \multicolumn{2}{|c|}{$\mathrm{m} 6$} \\
\cline { 2 - 3 } & \multicolumn{1}{|c|}{$\mathrm{m} 6\{\mathrm{P} 3\}=0.95$} & \multicolumn{1}{|c|}{$\mathrm{m} 6\{\theta\}=0.05$} \\
\hline $\mathrm{m} 5\{\mathrm{P} 3\}=0.9406$ & $\{\mathrm{P} 3\}=0.95 \times$ & $\{\mathrm{P}\}=0.05 \times 0.9406=$ \\
$\mathrm{m} 5\{\mathrm{P} 2, \mathrm{P} 3, \mathrm{P} 10\}$ & $0.9406=0.89357$ & 0.04703 \\
$=0.0497$ & $\{\mathrm{P} 3\}=0.95 \times$ & $\{\mathrm{P} 2, \mathrm{P} 3, \mathrm{P} 10\}=0.05 \times$ \\
& $0.0497=0.04721$ & $0.0497=0.0025$ \\
\hline $\mathrm{m} 5\{\theta\}=0.0097$ & $\{\mathrm{P} 3\}=0.95 \times$ & $\{\theta\}=0.05 \times 0.0097=$ \\
& $0.0097=0.00921$ & 0.00048 \\
\hline
\end{tabular}

Sehingga dapat dihitung sebagai berikut:

$\mathrm{m}_{7}\{\mathrm{P} 3\}=\frac{0.89357+0.04721+0.04703+0.00921}{1-0}=0.99703$

$\mathrm{m}_{7}\{\mathrm{P} 2, \mathrm{P} 3, \mathrm{P} 10\}=\frac{0.0025}{1-0}=0.0025$

$\mathrm{m}_{7}\{\theta\}=1-(0.99703+0.0025)=0.00047$

e. Gejala G05: Nyeri

$\mathrm{m}_{8}\{\mathrm{P} 5, \mathrm{P} 6, \mathrm{P} 8, \mathrm{P} 9\}==\frac{0.83+0.62+1+0.95}{4}=0.85$

$\mathrm{m}_{8}\{\theta\}=1-0.85=0.15$

TABEL VI. ATURAN KOMBINASI $\mathrm{M}_{9}$ UNTUK CONTOH KASUS PENGUJIAN TEORITIS

\begin{tabular}{|l|l|l|}
\hline \multirow{2}{*}{$\mathrm{m} 7$} & \multicolumn{2}{|c|}{$\mathrm{m} 8$} \\
\cline { 2 - 3 } & $\mathrm{m} 8\{\mathrm{P} 5, \mathrm{P} 6, \mathrm{P} 8, \mathrm{P} 9\}=$ & \multicolumn{1}{|c|}{$\mathrm{m} 8\{\theta\}=0.15$} \\
\hline $\mathrm{m} 7\{\mathrm{P} 3\}=$ & $\{\theta\}=0.85 \times 0.99703$ & $\{\mathrm{P} 3\}=0.15 \times$ \\
0.99703 & $=0.847475$ & $0.99703=0.14955$ \\
\hline
\end{tabular}




\begin{tabular}{|c|c|c|}
\hline $\begin{array}{l}\mathrm{m} 7\{\mathrm{P} 2, \mathrm{P} 3, \mathrm{P} 10\} \\
=0.0025\end{array}$ & $\begin{array}{l}\{\theta\}=0.85 \times 0.0025= \\
0.002112\end{array}$ & $\begin{array}{l}\{\mathrm{P} 2, \mathrm{P} 3, \mathrm{P} 10\}= \\
0.15 \times 0.0025= \\
0.00037\end{array}$ \\
\hline $\mathrm{m} 7\{\theta\}=0.00047$ & $\begin{array}{l}\{\mathrm{P} 5, \mathrm{P} 6, \mathrm{P} 8, \mathrm{P} 9\}= \\
0.85 \times 0.00047= \\
0.0004\end{array}$ & $\begin{array}{l}\{\theta\}=0.15 \times \\
0.00047=0.00007\end{array}$ \\
\hline
\end{tabular}

Sehingga dapat dihitung sebagai berikut:

$\mathrm{m}_{9}\{\mathrm{P} 3\}=\frac{0.14955}{1-0.849587}=0.99426$

$\mathrm{m}_{9}\{\mathrm{P} 2, \mathrm{P} 3, \mathrm{P} 10\}=\frac{0.00037}{1-0.849587}=0.00245$

$\mathrm{m}_{9}\{\mathrm{P} 5, \mathrm{P} 6, \mathrm{P} 8, \mathrm{P} 9\}=\frac{0.0004}{1-0.849587}=0.0026$

$\mathrm{m}_{9}\{\theta\}=1-(0.99426+0.00245+0.0026)=$

0.0006

Berdasarkan 5 gejala yang dimasukkan pengguna maka didapatkan nilai densitas yang paling tinggi yaitu pada penyakit kulit P3 yang merupakan kode penyakit Candidiasis dengan tingkat kepercayaan (densitas) sebesar 0.99426 atau dengan persentase sebesar $99,43 \%$.

Hasil konsultasi pada sistem jika dimasukkan 5 gejala pada contoh kasus dapat dilihat pada Gambar 6. Sistem memberikan hasil diagnosa penyakit Candidiasis dengan persentase sebesar $99.43 \%$, sehingga disimpulkan bahwa hasil perhitungan sistem telah sesuai dengan hasil perhitungan teoritis.

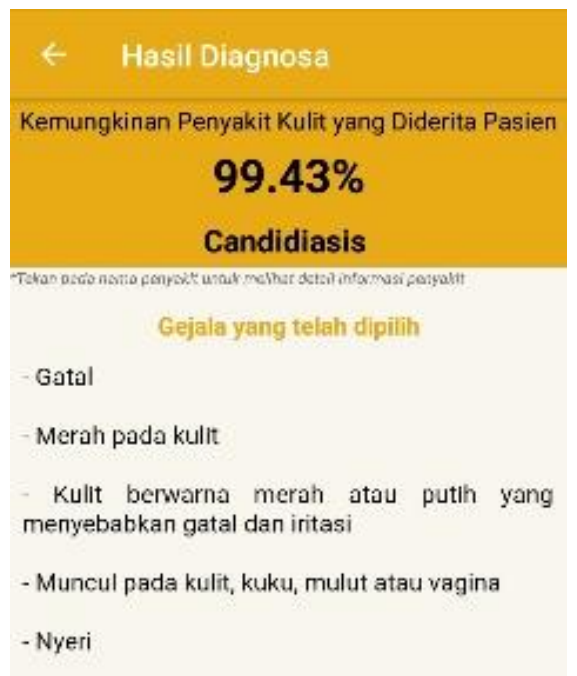

Gambar 6. Pengujian perhitungan metode Dempster Shafer pada sistem.

\section{B.3. Pengujian Akurasi Sistem}

Pengujian akurasi sistem dilakukan oleh 3 pakar yaitu 3 dokter spesialis kulit dan kelamin. Pengujian ini bertujuan untuk mengetahui kesesuaian antara hasil diagnosa pakar dan hasil diagnosa sistem. Pengujian ini dilakukan pada 30 contoh kasus dimana data kasus diberikan oleh pakar 1.30 contoh kasus yang diberikan tersebut kemudian diujikan kepada 2 pakar lainnya.

Pengujian akurasi 30 contoh kasus yang diberikan kepada 3 pakar dapat dilihat pada tautan: https://drive.google.com/file/d/1 fw3v2EiSfHaIWdne9Bz4 eZ5fip3Zwqqj/view?usp=sharing. Perbandingan hasil pengujian pakar dapat dilihat pada Tabel VII untuk pakar 1, Tabel VIII untuk pakar 2 dan Tabel IX untuk pakar 3.
TABEL VII. PENGUJIAN AKURASI PAKAR 1

\begin{tabular}{|c|c|c|c|}
\hline $\begin{array}{c}\text { Pengujian } \\
\text { ke- }\end{array}$ & $\begin{array}{c}\text { Hasil diagnosa } \\
\text { pakar } 1\end{array}$ & $\begin{array}{c}\text { Hasil diagnosa } \\
\text { sistem }\end{array}$ & Ket. \\
\hline 1 & Scabies, Tinea & Scabies $69.26 \%$ & $\begin{array}{l}\text { Tidak } \\
\text { Valid }\end{array}$ \\
\hline 2 & $\begin{array}{l}\text { Cutaneous Larva } \\
\text { Migran }\end{array}$ & $\begin{array}{l}\text { Cutaneous Larva } \\
\text { Migran } 100.0 \%\end{array}$ & Valid \\
\hline 3 & Impetigo Krustosa & $\begin{array}{l}\text { Impetigo } \quad \text { Krustosa } \\
99.35 \%\end{array}$ & Valid \\
\hline 4 & Scabies & Scabies $64.78 \%$ & Valid \\
\hline 5 & Varicella & Varicella $99.44 \%$ & Valid \\
\hline 6 & Candidiasis & Candidiasis $99.87 \%$ & Valid \\
\hline 7 & Tinea & Tinea $98.68 \%$ & Valid \\
\hline 8 & Candidiasis & Candidiasis $99.76 \%$ & Valid \\
\hline 9 & Impetigo Bulosa & $\begin{array}{ll}\text { Impetigo } & \text { Bulosa } \\
99.57 \% & \end{array}$ & Valid \\
\hline 10 & Varicella & Varicella $92.3 \%$ & Valid \\
\hline 11 & Herpes Zoster & Herpes Zoster $99.99 \%$ & Valid \\
\hline 12 & Candidiasis & Candidiasis $99.43 \%$ & Valid \\
\hline 13 & Herpes Zoster & Herpes Zoster $99.58 \%$ & Valid \\
\hline 14 & Impetigo Krustosa & $\begin{array}{l}\text { Impetigo } \quad \text { Krustosa } \\
99.96 \%\end{array}$ & Valid \\
\hline 15 & Impetigo Krustosa & $\begin{array}{ll}\text { Impetigo } & \text { Krustosa } \\
98.96 \% & \\
\end{array}$ & Valid \\
\hline 16 & Impetigo Bulosa & $\begin{array}{l}\text { Impetigo } \quad \text { Bulosa } \\
86.89 \%\end{array}$ & Valid \\
\hline 17 & Herpes Zoster & Herpes Zoster $96.18 \%$ & Valid \\
\hline 18 & Selulitis & Selulitis $99.82 \%$ & Valid \\
\hline 19 & Impetigo Bulosa & $\begin{array}{ll}\text { Impetigo } & \text { Bulosa } \\
98.35 \% & \\
\end{array}$ & Valid \\
\hline 20 & Selulitis & Selulitis $95.09 \%$ & Valid \\
\hline 21 & Karbunkel & Karbunkel $99.97 \%$ & Valid \\
\hline 22 & Karbunkel & Karbunkel $99.99 \%$ & Valid \\
\hline 23 & Karbunkel & Karbunkel $99.5 \%$ & Valid \\
\hline 24 & $\begin{array}{l}\text { Cutaneous Larva } \\
\text { Migran }\end{array}$ & $\begin{array}{l}\text { Cutaneous Larva } \\
\text { Migran } 100.0 \%\end{array}$ & Valid \\
\hline 25 & Tinea & Tinea $95.95 \%$ & Valid \\
\hline 26 & Scabies & Scabies $70.46 \%$ & Valid \\
\hline 27 & Tinea & Tinea $98.71 \%$ & Valid \\
\hline 28 & Varicella & Varicella $99.37 \%$ & Valid \\
\hline 29 & Impetigo Bulosa & $\begin{array}{ll}\text { Impetigo } & \text { Bulosa } \\
85.15 \% & \\
\end{array}$ & Valid \\
\hline 30 & Selulitis & Selulitis $99.94 \%$ & Valid \\
\hline
\end{tabular}

Pada Tabel VII, berdasarkan 30 contoh kasus yang dibandingkan dengan hasil diagnosa pakar 1 terdapat 29 kasus yang sesuai dan 1 kasus tidak sesuai yaitu pada pengujian kasus ke-1, sehingga diperoleh nilai keakuratan pakar 1 sebesar $\frac{29}{30} \times 100 \%=96.67 \%$. Hasil diagnosa yang tidak valid pada pada kasus ke-1 disebabkan karena kesimpulan hasil diagnosa dalam perhitungan metode Dempster Shafer merupakan penyakit dengan nilai densitas tertinggi, sehingga hanya menghasilkan 1 penyakit yaitu Scabies.

Jika hasil diagnosa sistem dianggap valid pada kasus ke-1 karena hasil diagnosa sistem merupakan himpunan bagian dari hasil diagnosa pakar 1, maka diperoleh hasil akurasi sistem yang lebih tinggi yaitu sebesar $\frac{30}{30} \times 100 \%=$ $100 \%$.

Pada Tabel VIII, berdasarkan 30 contoh kasus yang dibandingkan dengan hasil diagnosa pakar 2 terdapat 26 kasus yang sesuai dan 4 kasus tidak sesuai yaitu pada pengujian kasus ke-1, kasus ke-19, kasus ke-26 dan kasus ke-29, sehingga diperoleh nilai keakuratan pakar 2 sebesar $\frac{26}{30} \times 100 \%=86.67 \%$. 
TABEL VIII. PENGUJIAN AKURASI PAKAR 2

\begin{tabular}{|c|c|c|c|}
\hline $\begin{array}{c}\text { Pengujian } \\
\text { ke- }\end{array}$ & $\begin{array}{c}\text { Hasil diagnosa } \\
\text { pakar } 2\end{array}$ & $\begin{array}{c}\text { Hasil diagnosa } \\
\text { sistem }\end{array}$ & Ket. \\
\hline 1 & Impetigo Bulosa & Scabies $69.26 \%$ & $\begin{array}{l}\text { Tidak } \\
\text { Valid }\end{array}$ \\
\hline 2 & $\begin{array}{l}\text { Cutaneous Larva } \\
\text { Migran }\end{array}$ & $\begin{array}{l}\text { Cutaneous Larva } \\
\text { Migran } 100.0 \%\end{array}$ & Valid \\
\hline 3 & Impetigo Krustosa & $\begin{array}{l}\text { Impetigo Krustosa } \\
99.35 \%\end{array}$ & Valid \\
\hline 4 & Scabies & Scabies $64.78 \%$ & Valid \\
\hline 5 & Varicella & Varicella $99.44 \%$ & Valid \\
\hline 6 & Candidiasis & Candidiasis $99.87 \%$ & Valid \\
\hline 7 & Tinea & Tinea $98.68 \%$ & Valid \\
\hline 8 & Candidiasis & Candidiasis $99.76 \%$ & Valid \\
\hline 9 & Impetigo Bulosa & $\begin{array}{ll}\text { Impetigo } & \text { Bulosa } \\
99.57 \% & \\
\end{array}$ & Valid \\
\hline 10 & Varicella & Varicella $92.3 \%$ & Valid \\
\hline 11 & Herpes Zoster & Herpes Zoster $99.99 \%$ & Valid \\
\hline 12 & Candidiasis & Candidiasis $99.43 \%$ & Valid \\
\hline 13 & Herpes Zoster & Herpes Zoster $99.58 \%$ & Valid \\
\hline 14 & Impetigo Krustosa & $\begin{array}{l}\text { Impetigo } \quad \text { Krustosa } \\
99.96 \%\end{array}$ & Valid \\
\hline 15 & Impetigo Krustosa & $\begin{array}{l}\text { Impetigo Krustosa } \\
98.96 \%\end{array}$ & Valid \\
\hline 16 & Impetigo Bulosa & $\begin{array}{l}\text { Impetigo } \quad \text { Bulosa } \\
86.89 \%\end{array}$ & Valid \\
\hline 17 & Herpes Zoster & Herpes Zoster $96.18 \%$ & Valid \\
\hline 18 & Selulitis & Selulitis $99.82 \%$ & Valid \\
\hline 19 & Karbunkel & $\begin{array}{ll}\text { Impetigo } & \text { Bulosa } \\
98.35 \% & \\
\end{array}$ & $\begin{array}{l}\text { Tidak } \\
\text { Valid }\end{array}$ \\
\hline 20 & Selulitis & Selulitis $95.09 \%$ & Valid \\
\hline 21 & Karbunkel & Karbunkel $99.97 \%$ & Valid \\
\hline 22 & Karbunkel & Karbunkel $99.99 \%$ & Valid \\
\hline 23 & Karbunkel & Karbunkel $99.5 \%$ & Valid \\
\hline 24 & $\begin{array}{l}\text { Cutaneous Larva } \\
\text { Migran }\end{array}$ & $\begin{array}{l}\text { Cutaneous Larva } \\
\text { Migran } 100.0 \%\end{array}$ & Valid \\
\hline 25 & Tinea & Tinea $95.95 \%$ & Valid \\
\hline 26 & Tinea & Scabies $70.46 \%$ & $\begin{array}{l}\text { Tidak } \\
\text { Valid }\end{array}$ \\
\hline 27 & Tinea & Tinea $98.71 \%$ & Valid \\
\hline 28 & Varicella & Varicella $99.37 \%$ & Valid \\
\hline 29 & Selulitis & $\begin{array}{ll}\text { Impetigo } & \text { Bulosa } \\
85.15 \% & \\
\end{array}$ & $\begin{array}{l}\text { Tidak } \\
\text { Valid }\end{array}$ \\
\hline 30 & Selulitis & Selulitis $99.94 \%$ & Valid \\
\hline
\end{tabular}

Pada Tabel IX, berdasarkan 30 contoh kasus yang dibandingkan dengan hasil diagnosa pakar 3 terdapat 26 kasus yang sesuai dan 4 kasus tidak sesuai yaitu pada pengujian kasus ke-1, kasus ke-26, kasus ke-29 dan kasus ke-30, sehingga diperoleh nilai keakuratan pakar 3 sebesar $=\frac{26}{30} \times 100 \%=86.67 \%$. Hasil diagnosa yang tidak valid pada pada kasus ke-1 disebabkan karena kesimpulan hasil diagnosa dalam perhitungan metode Dempster Shafer merupakan penyakit dengan nilai densitas tertinggi, sehingga hanya menghasilkan 1 penyakit yaitu Scabies.

Jika hasil diagnosa sistem dianggap valid pada kasus ke-1 karena hasil diagnosa sistem merupakan himpunan bagian dari hasil diagnosa pakar 3, maka diperoleh hasil akurasi sistem yang lebih tinggi yaitu sebesar $\frac{27}{30} \times 100 \%=$ $90 \%$.

Setelah dilakukan perhitungan nilai keakuratan hasil diagnosa sistem dari ketiga pakar, maka dilakukan perhitungan untuk mendapatkan nilai rata-rata persentase akurasi ketiga pakar dengan menggunakan Persamaan (6).
TABEL IX. PENGUJIAN AKURASI PAKAR 3

\begin{tabular}{|c|c|c|c|}
\hline $\begin{array}{l}\text { Pengujian } \\
\text { ke- }\end{array}$ & $\begin{array}{c}\text { Hasil diagnosa } \\
\text { pakar } 3\end{array}$ & $\begin{array}{c}\text { Hasil diagnosa } \\
\text { sistem }\end{array}$ & Ket. \\
\hline 1 & $\begin{array}{l}\text { Scabies, Tinea, } \\
\text { Candidiasis }\end{array}$ & Scabies $69.26 \%$ & $\begin{array}{l}\text { Tidak } \\
\text { Valid }\end{array}$ \\
\hline 2 & $\begin{array}{l}\text { Cutaneous Larva } \\
\text { Migran }\end{array}$ & $\begin{array}{l}\text { Cutaneous Larva } \\
\text { Migran } 100.0 \%\end{array}$ & Valid \\
\hline 3 & Impetigo Krustosa & $\begin{array}{l}\text { Impetigo } \quad \text { Krustosa } \\
99.35 \%\end{array}$ & Valid \\
\hline 4 & Scabies & Scabies $64.78 \%$ & Valid \\
\hline 5 & Varicella & Varicella $99.44 \%$ & Valid \\
\hline 6 & Candidiasis & Candidiasis $99.87 \%$ & Valid \\
\hline 7 & Tinea & Tinea $98.68 \%$ & Valid \\
\hline 8 & Candidiasis & Candidiasis $99.76 \%$ & Valid \\
\hline 9 & Impetigo Bulosa & $\begin{array}{ll}\text { Impetigo } & \text { Bulosa } \\
99.57 \% & \\
\end{array}$ & Valid \\
\hline 10 & Varicella & Varicella $92.3 \%$ & Valid \\
\hline 11 & Herpes Zoster & Herpes Zoster $99.99 \%$ & Valid \\
\hline 12 & Candidiasis & Candidiasis $99.43 \%$ & Valid \\
\hline 13 & Herpes Zoster & Herpes Zoster $99.58 \%$ & Valid \\
\hline 14 & Impetigo Krustosa & $\begin{array}{l}\text { Impetigo } \quad \text { Krustosa } \\
99.96 \%\end{array}$ & Valid \\
\hline 15 & Impetigo Krustosa & $\begin{array}{l}\text { Impetigo } \quad \text { Krustosa } \\
98.96 \%\end{array}$ & Valid \\
\hline 16 & Impetigo Bulosa & $\begin{array}{l}\text { Impetigo } \quad \text { Bulosa } \\
86.89 \%\end{array}$ & Valid \\
\hline 17 & Herpes Zoster & Herpes Zoster $96.18 \%$ & Valid \\
\hline 18 & Selulitis & Selulitis $99.82 \%$ & Valid \\
\hline 19 & Impetigo Bulosa & $\begin{array}{ll}\text { Impetigo } & \text { Bulosa } \\
98.35 \% & \\
\end{array}$ & Valid \\
\hline 20 & Selulitis & Selulitis $95.09 \%$ & Valid \\
\hline 21 & Karbunkel & Karbunkel $99.97 \%$ & Valid \\
\hline 22 & Karbunkel & Karbunkel $99.99 \%$ & Valid \\
\hline 23 & Karbunkel & Karbunkel $99.5 \%$ & Valid \\
\hline 24 & $\begin{array}{l}\text { Cutaneous Larva } \\
\text { Migran }\end{array}$ & $\begin{array}{l}\text { Cutaneous Larva } \\
\text { Migran } 100.0 \%\end{array}$ & Valid \\
\hline 25 & Tinea & Tinea $95.95 \%$ & Valid \\
\hline 26 & Tinea & Scabies $70.46 \%$ & $\begin{array}{l}\text { Tidak } \\
\text { Valid }\end{array}$ \\
\hline 27 & Tinea & Tinea $98.71 \%$ & Valid \\
\hline 28 & Varicella & Varicella $99.37 \%$ & Valid \\
\hline 29 & $\begin{array}{l}\text { Varicella, Herpes } \\
\text { Zoster }\end{array}$ & $\begin{array}{ll}\text { Impetigo } & \text { Bulosa } \\
85.15 \% & \\
\end{array}$ & $\begin{array}{l}\text { Tidak } \\
\text { Valid }\end{array}$ \\
\hline 30 & Karbunkel & Selulitis $99.94 \%$ & $\begin{array}{l}\text { Tidak } \\
\text { Valid }\end{array}$ \\
\hline
\end{tabular}

Nilai rata-rata akurasi sistem

$=\frac{\text { nilai keakuratan pakar } 1+\text { nilai keakuratan pakar } 2+\text { nilai keakuratan pakar } 3}{3}$

$$
\begin{aligned}
& =\frac{96.67 \%+86.67 \%+86.67 \%}{3} \\
& =90 \%
\end{aligned}
$$

Namun jika hasil diagnosa sistem dianggap valid karena hasil diagnosa sistem merupakan himpunan bagian dari hasil diagnosa pakar, maka didapatkan nilai rata-rata persentase akurasi ketiga pakar adalah sebagai berikut.

Nilai rata-rata akurasi sistem

$$
\begin{aligned}
& =\frac{100 \%+86.67 \%+90 \%}{3} \\
& =92.22 \%
\end{aligned}
$$

Berdasarkan perhitungan pengujian akurasi yang dilakukan dapat diketahui nilai akurasi sistem pakar diagnosa penyakit kulit pada manusia dengan metode Dempster Shafer berdasarkan 30 contoh kasus yaitu sebesar 90\%. Namun, jika hasil diagnosa sistem dianggap 
valid karena diasumsikan sebagai himpunan bagian dari hasil diagnosa pakar, maka nilai akurasi sistem sebesar $92.22 \%$. Perbedaan pengetahuan dan pengalaman yang dimiliki oleh masing-masing pakar menyebabkan perbedaan hasil diagnosa yang diberikan.

\section{B.4. Pengujian MOS (Mean Opinion Score)}

Pengujian MOS dilakukan dengan tujuan untuk mengetahui kelayakan dari sistem pakar diagnosa penyakit kulit yang dibangun. Penilaian mengenai sistem diberikan oleh responden melalui kuesioner. Responden dalam pengujian ini berjumlah 35 yang terdiri dari 26 mahasiswa, 4 tenaga medis (perawat) dan 5 masyarakat umum (pegawai dan ibu rumah tangga). Responden mahasiswa terdiri dari 17 mahasiswa Program Studi Teknik Informatika yang memahami tentang sistem serta 5 mahasiswa fakultas kedokteran dan 4 mahasiswa dari fakultas lain yang merupakan pengguna android biasa. Pengujian MOS pada 17 mahasiswa Teknik Informatika dilakukan di Laboratorium Sistem Cerdas Program Studi Teknik Informatika Universitas Mataram serta pengujian MOS pada 9 mahasiswa, 4 tenaga medis dan 5 masyarakat umum dilakukan di lapangan.

Berdasarkan penilaian yang diberikan oleh responden pada setiap pertanyaan kuesioner kemudian akan dihitung skor rata-rata jawaban seperti pada Persamaan (7)[18].

$$
\mu_{p i}=\frac{\sum S_{i} \cdot B_{i}}{n}
$$

dimana:

$$
\begin{aligned}
\mu_{p i}= & \text { rata }- \text { rata skor setiap atribut pertanyaan } \\
S i & =\text { jumlah responden yang memilih setiap atribut } \\
B i & =\text { jawaban } \\
n= & \text { jobot setiap atribut pertanyaan responden }
\end{aligned}
$$

Selanjutnya untuk mendapatkan kesimpulan hasil pengujian ini dilakukan dengan menghitung MOS berdasarkan total skor rata-rata pada seluruh atribut pertanyaan menggunakan Persamaan (8)[18].

$$
\text { MOS }=\frac{\sum_{i=1}^{k} \mu_{p i}}{k}
$$

\begin{tabular}{|c|c|c|c|c|c|c|c|c|}
\hline $\begin{array}{l}\mathbf{N} \\
\mathbf{0} \\
\end{array}$ & Pertanyaan & SS & $\mathbf{S}$ & $\begin{array}{l}\mathbf{T} \\
\mathbf{T} \\
\end{array}$ & $\begin{array}{l}\mathbf{T} \\
\mathbf{S} \\
\end{array}$ & STS & Tot & $\boldsymbol{\mu}_{p i}$ \\
\hline 1 & Pertanyaan 1 & 17 & 18 & - & - & - & 35 & 4.49 \\
\hline 2 & Pertanyaan 2 & 9 & 23 & 2 & 1 & - & 35 & 4.14 \\
\hline 3 & Pertanyaan 3 & 17 & 18 & - & - & - & 35 & 4.49 \\
\hline 4 & Pertanyaan 4 & 20 & 14 & 1 & - & - & 35 & 4.54 \\
\hline 5 & Pertanyaan 5 & 9 & 20 & 6 & - & - & 35 & 4.10 \\
\hline & Sub Total & 72 & 93 & 9 & 1 & - & 175 & 21.76 \\
\hline
\end{tabular}

dimana:

MOS = total skor rata-rata seluruh atribut pertanyaan

$k \quad=$ jumlah atribut pertanyaan

TABEL X. HASIL PENGUJIAN MOS
Keterangan:

Pertanyaan 1: Tampilan sistem pakar diagnosa penyakit kulit pada manusia ini menarik dan mudah digunakan (user friendly)

Pertanyaan 2: Penggunaan warna tampilan dan jenis huruf pada sistem pakar ini sudah sesuai

Pertanyaan 3: Adanya sistem pakar ini dapat memberikan informasi saran penanganan dan pencegahan penyakit kulit

Pertanyaan 4: Adanya sistem pakar ini dapat membantu untuk melakukan diagnosa penyakit kulit menjadi lebih mudah

Pertanyaan 5: Anda akan menggunakan sistem pakar ini untuk membantu melakukan diagnosa penyakit kulit Anda pada waktu yang akan datang

Hasil pengujian parameter MOS yang diberikan oleh 35 responden dapat dilihat pada Tabel $\mathrm{X}$ dan penilaian masing-masing responden terhadap sistem pakar diagnosa penyakit kulit pada manusia ini dapat dilihat pada tautan: https://drive.google.com/file/d/1UuOYoyyj7Q5RLIHnfP USzt1mRrjVUj1O/view?usp=sharing.

Berdasarkan hasil pengujian MOS pada Tabel X yang diperoleh dari hasil kuesioner 35 responden didapatkan kesimpulan hasil perhitungan MOS sebesar 4.35 dari skala 5. Nilai ini menunjukkan bahwa kualitas sistem pakar diagnosa penyakit kulit pada manusia dengan metode Dempster Shafer yang dibangun sudah baik, tampilan sistem menarik, sistem memudahkan dalam diagnosa penyakit kulit, memberikan informasi mengenai penyakit kulit dan sistem juga dapat tetap digunakan oleh masyarakat di waktu yang akan datang untuk membantu melakukan diagnosa penyakit kulit. Sistem dengan rentang nilai MOS 4 sampai dengan 5 dikelompokkan ke dalam kategori sistem good (baik).

\section{KESIMPULAN DAN SARAN}

\section{A. Kesimpulan}

Berdasarkan hasil analisis dan pengujian pada sistem pakar diagnosa penyakit kulit pada manusia dengan metode Dempster Shafer, maka diperoleh kesimpulan sebagai berikut:

1. Berdasarkan hasil pengujian akurasi sistem didapatkan kesimpulan nilai rata-rata akurasi sistem yaitu sebesar $90 \%$ berdasarkan 30 contoh kasus yang diujikan pada 3 orang pakar. Namun, jika hasil diagnosa sistem dipandang sebagai himpunan bagian dari hasil diagnosa pakar, maka nilai akurasi sistem yaitu sebesar $92.22 \%$.

2. Berdasarkan hasil pengujian MOS (Mean Opinion Score) didapatkan nilai MOS sebesar 4.35 dari skala 5 yang menunjukkan bahwa sistem layak digunakan dan dikategorikan ke dalam sistem yang baik.

3. Berdasarkan pada hasil pengujian akurasi dan MOS yang dilakukan, maka sistem pakar diagnosa penyakit kulit pada manusia ini telah berhasil diimplementasikan ke dalam sistem untuk mendiagnosa 10 jenis penyakit kulit yang disebabkan oleh virus, jamur, bakteri dan 
parasit dengan menerapkan metode Dempster Shafer untuk mengambil kesimpulan berdasarkan pada pengetahuan 3 orang pakar.

\section{B. Saran}

Adapun saran yang dapat diberikan dalam pengembangan sistem ini agar menjadi lebih baik adalah sebagai berikut.

1. Sistem pakar diagnosa penyakit kulit pada manusia ini diharapkan untuk dikembangkan dengan menerapkan metode sistem pakar yang lain agar dapat dilakukan perbandingan metode yang lebih tepat digunakan untuk mengambil kesimpulan diagnosa penyakit kulit.

2. Peneliti disarankan untuk melakukan konsultasi data gejala penyakit yang telah dikumpulkan kepada seluruh pakar sebelum dilakukan pembobotan.

3. Pada sistem pakar ini diharapkan adanya penambahan fungsi untuk melakukan update pada basis pengetahuan.

4. Pengembangan sistem selanjutnya diharapkan dapat dibuat dengan arsitektur client-server agar dapat dilakukan sinkronisasi database ke server sehingga data hasil diagnosa yang pernah dilakukan dapat terintegrasi dan juga dapat digunakan untuk pembelajaran mesin agar sistem dapat memberikan hasil diagnosa yang lebih akurat.

\section{DAFTAR PUSTAKa}

[1] B. Sukahar, "Sistem Pakar Diagnosa Penyakit Kulit Menggunakan Metode Forward dan Backward Chaining Berbasis Web," Universitas Kanjuruhan Malang, 2014.

[2] Melizar and Z. Yunizar, "Sistem Pakar Diagnosa Penyakit Kulit pada Manusia Menggunakan Metode DempsterShafer," J. TIKA, vol. 1, no. 1, pp. 113-118, 2016.

[3] F. Nuraeni, Y. H. Agustin, and E. N. Yusup, "Aplikasi Pakar Untuk Diagnosa Penyakit Kulit Menggunakan Metode Forward Chaining Di Al Arif Skin Care Kabupaten Ciamis," Semin. Nas. Teknol. Inf. dan Multimed., vol. 4, no. 1, pp. 55-60, 2016.

[4] M. A. C. Bumi, "Sistem Pakar untuk Mendeteksi Penyakit Kulit dan Kelamin dengan Metode Forward Chaining," Universitas Pembangunan Nasional Veteran Jawa Timur, 2010.

[5] Dinas Kesehatan Provinsi NTB, "Profil Kesehatan Provinsi Nusa Tenggara Barat Tahun 2017," 2017.

[6] M. Ihsan, F. Agus, and D. M. Khairina, "Penerapan Metode Dempster Shafer Untuk Sistem Deteksi Penyakit Tanaman Padi," Pros. Semin. Ilmu Komput. dan Teknol. Inf., vol. 2, no. 1, pp. 128-135, 2017.

[7] A. P. Putra and C. Rahmad, "Analisa Perbandingan Metode Certainty Factor dan Dempster Shafer pada Sistem Pakar Diagnosa Penyakit Diabetes Melitus," J. Inform. Polinema, vol. 2, no. 1, pp. 7-12, 2015.

[8] Husain, A. T. Wibowo, and E. Ariyanto, "Analisis Perbandingan Sistem Pakar untuk Mendiagnosis Penyakit Mulut dan Gigi pada Manusia dengan Menggunakan Certainty Factor dan Teori Dempster-Shafer," Universitas Telkom, 2010.

[9] R. Hamidi, H. Anra, and H. S. Pratiwi, "Analisis Perbandingan Sistem Pakar Dengan Metode Certainty Factor dan Metode Dempster-Shafer Pada Penyakit Kelinci," J. Sist. dan Teknol. Inf., vol. 5, no. 2, pp. 142147, 2017.

[10] L. K. Wardhani and R. Kurniawan, "Analisis Perbandingan Metode Bayesian Network dan Dempster-Shafer Pada Sistem Pakar Diagnosis Penyakit Mata," Semin. Nas. Teknol. Inf. Komun. dan Ind. 4, pp. 239-244, 2012.

[11] F. Supandi, A. Budiman, and Kusrini, "Penerapan Metode Dempster-Shafer dalam Pembangunan Sistem Pakar Diagnosa Penyakit Kulit," in Prosiding Seminar Nasional Aplikasi Sains \& Teknologi (SNAST), 2018, pp. 197-205.

[12] F. Firmansyah, "Aplikasi Sistem Pakar Diagnosa Penyakit Kulit dengan Menerapkan Metode Dempster-Shafer," Universitas Airlangga, 2016.

[13] M. Indriani, A. Farmadi, and Muliadi, "Penerapan Metode Fuzzy Mamdani dan Dempster Shafer pada Diagnosa Awal Penyakit Kulit," J. Elektron. Nas. Teknol. dan Ilmu Komput., pp. 232-246, 2017.

[14] K. S. Permana, "Ketika Pengguna Internet dan Smartphone Terus Meningkat, Android Dominasi Pasar Indonesia dan Dunia," TribunJabar.id, 2019.

[15] V. Kemala, B. Irawan, and M. Nasrun, "Rancang Bangun Aplikasi Sistem Pakar Untuk Diagnosis Penyakit Kulit Dan Kelamin Berbasis Smartphone Android," eProceedings Eng., vol. 2, no. 2, pp. 3568-3574, 2015.

[16] I. P. B. Krisnawan, I. K. G. D. Putra, and I. P. A. Bayupati, "Sistem Pakar Diagnosa Penyakit Kulit dan Kelamin dengan Metode Certainty Factor dan Fuzzy Logic," J. Ilm. Merpati, vol. 2, no. 3, pp. 351-360, 2014.

[17] M. T. P. Katili, "Penerapan Metode Bayesian Network dalam Membangun Sistem Pakar Diagnosa Penyakit Kulit pada Manusia,” Universitas Negeri Gorontalo, 2013.

[18] D. Hastari and F. Bimantoro, "Sistem Pakar untuk Mendiagnosis Gangguan Mental Anak Menggunakan Metode Dempster Shafer," J-COSINE, vol. 2, no. 2, pp. 71-79, 2018

[19] S. Orthega, N. Hidayat, and E. Santoso, "Implementasi Metode Dempster-Shafer untuk Mendiagnosa Penyakit Tanaman Padi," J. Pengemb. Teknol. dan Ilmu Komput., vol. 1, no. 10, pp. 1240-1247, 2017. 